\title{
The activeness, critical, and creative thinking skills of students in the lesson study-based inquiry and cooperative learning
}

\author{
Rusdi Hasan a,1,* Marheny Lukitasari b,2, Sri Utami a,3, Anizar c,4 \\ a Department of Biology Education, Universitas Muhammadiyah Bengkulu, Jl. Bali, Teluk Segara, Bengkulu, 38119, Indonesia \\ ${ }^{-}$Department of Biology Education, Universitas PGRI Madiun, Address, Jl. Setia Budi No. 85, Madiun, East Java, 63118, Indonesia \\ c Madrasah Aliyah Negeri 2 of Bengkulu (Islamic Senior High School), Jl. Bandara Fatmawati 13/05, Bengkulu, 38213, Indonesia \\ rusdihasan@umb.ac.id*; ${ }^{2}$ marheny@unipma.ac.id; ${ }^{3}$ utamisri101@gmail.com; ${ }^{4}$ anizarbengkulu@gmail.com; \\ * corresponding author
}

\begin{tabular}{|c|c|}
\hline ARTICLE INFO & ABSTRACT \\
\hline $\begin{array}{l}\text { Article history } \\
\text { Received January 04, } 2019 \\
\text { Revised January 31, 2019 } \\
\text { Accepted February 23, } 2019 \\
\text { Published March 05, } 2019 \\
\text { Keywords } \\
\text { Critical thinking } \\
\text { Creative thinking } \\
\text { Inquiry } \\
\text { Lesson study }\end{array}$ & $\begin{array}{l}\text { The implementation of innovative learning and lesson study (LS) are potential to } \\
\text { improve student thinking skills and activeness differently and mostly implemented } \\
\text { separately. This study aimed to explore and compare the student critical and creative } \\
\text { thinking skills as well as student activeness in the inquiry and cooperative models } \\
\text { combined with LS-based learning practice. This was a descriptive quantitative study } \\
\text { that was conducted at Islamic Senior High School } 1 \text { of Bengkulu. The sample was two } \\
\text { classes consisted of } 33 \text { and } 32 \text { students each that conducted LS-inquiry and LS- } \\
\text { cooperative learning. The essay test delivered to measure critical and creative thinking } \\
\text { skills and observation sheet to measure student activeness. The data were analyzed by } \\
\text { t-test to compare critical and creative thinking skills as well as the student activeness } \\
\text { between the LS-inquiry and LS-cooperative classes. The result showed that LS-inquiry } \\
\text { learning improved the student critical and creative thinking skills that significantly higher } \\
\text { than LS-cooperative learning. The student activeness improved gradually as LS cycles } \\
\text { during learning processes in either inquiry or cooperative learning, but no significant } \\
\text { difference between these two learning models. It showed that inquiry learning plays a } \\
\text { dominant influence in critical and creative thinking skills improvement, whereas LS in } \\
\text { student activeness improvement otherwise. } \\
\text { This is an open access article under the CC-BY-SA license } \\
\text { a }\end{array}$ \\
\hline
\end{tabular}

\section{INTRODUCTION}

The education quality in Indonesia is still quite far behind other countries in the world including ASEAN countries (Rahabav, 2016). Based on the results of the Organization for Economic Cooperation and Development (OECD) survey through the ranking of world education related to the Program for International Student Assessment (PISA), Indonesia ranked $62^{\text {nd }}$ out of 70 countries in terms of science literacy with the score 402, far below the average score OECD of 493 (Schleicher, 2018; Schleicher \& Echazarra, 2016). The low quality of education is one of the four main problems of education field in Indonesia apart from its equity, efficiency, and relevancy (Kurniawan, 2016). Quality educators, curriculum, the availability of educational facilities and infrastructures synergize in supporting the implementation of quality learning processes to 
produce a good quality outcome. The low quality of the learning process often associated with the low competency and creativity of educators carry out a learning process that involves student actively in learning and implements a student-centered learning process to develop higher-order thinking skills. Leow and Neo (2014) stated that the tendency of teacher-centered learning processes that emphasize the ability to memorize subject matter results in the inability of students to apply the concepts of learning with daily life was a problem of learning practices should address.

The information and communication technology rapidly develop in the 21 st-Century provides the broadest opportunity to innovate in various fields of life, including the educational. The era that leads to open and increasingly fierce competition globally to acquire and improve life skills following the needs of modern society. Bellanca et al (2010); Dwyer, Hogan, and Stewart (2014) developed the 21 st-Century learning framework that includes three skills as the outcome of the learning process which consist of (1) life and career skills, (2) learning and innovation skills, and (3) information media and technology skills. For the learning and innovation skills, the learning practice in schools today must be able to provide students with four abilities: creativity, critical thinking, collaboration and communication that simply called 4C. In Bloom's taxonomy, these 4C abilities are in the realm of higher-order thinking skill (HOTS).

Johnson (2002) has divided HOTS into critical and creative thinking skills. Ennis (1985) defined critical thinking from a philosophical tradition approach as the reflective and reasonable thinking that focused on deciding what to believe or do. On the cognitive psychological approach, Willingham (2008) stated that critical thinking as seeing both sides of an issue, being open to new evidence that disconfirms your ideas, reasoning dispassionately, demanding that claims be backed by evidence, deducing, and inferring conclusions from available facts, and solving problems. While, thinking ability that is able to produce imagination, new ideas, alternative hypotheses, and evaluation abilities are categorized as creative thinking (Kampylis \& Berki, 2014).

The critical and creative thinking skills of students are essential abilities in the global competition era of the

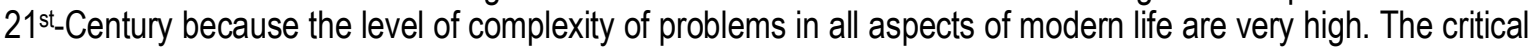
and creative thinking belongs to the high level of a cognitive domain as a continuation of essential competencies in the learning process (Chang, Li, Chen, \& Chiu, 2014; Huff, 2014; Lai, 2011; Liu, He, \& Li, 2015; Piergiovanni, 2014). Nowadays, it strongly emphasized that learners can acquire those skills after learning process through innovative learning models that enable to foster it. However, practically at schools as also happened at Islamic Senior High School/Madrasah Aliyah Negeri (MAN) 1 of Bengkulu, many teachers have not applied yet the innovative learning models characterized by student-centered learning to develop high-order thinking skills of the students. The preliminary observation found that the average student-learning outcome and activeness during the learning process of academic year 2106/2017 in biology subject were lower than minimum completeness criteria. This fact might relate to the lack of teachers' creativity to implement innovative strategies, models and learning approach in order to maximize the learning outcome.

The student can obtain the expected outcome as the teacher precisely chooses a learning model that conforms to the material and conditions of the learning environment. One alternative learning model aligns with the student activeness for gaining a high order thinking skill is an inquiry (Madhuri, Kantamreddi, \& PrakashGoteti, 2012). It have been reported elsewhere that the implementation of inquiry learning improved the student achievement (Jiang \& McComas, 2015), scientific performance (Kruit, Oostdam, Berg, \& Schuitema, 2018), activeness (Jocz, Zhai, \& Tan, 2014), critical thinking (Falahudin, Wigati, \& Pujiastuti, 2016; Miri, David, \& Uri, 2007; Tzelepi \& Papanikolaou, 2018), and creative thinking (Cremin, Glauert, Craft, Compton, \& Styliandou, 2015; Liu et al., 2015; Thompson, 2017).

On the other hand, for delivering the student to achieve an expected learning outcome, the teachers often face trouble in compiling and applying critical and creative thinking skills as well as designing a suitable strategy and so in observing student's activity optimally during the learning process by him or herself individually. These conditions require efforts to improve the quality of learning through a series of activities involving some teachers. One of the efforts to overcome this problem is by applying LS in the learning practices. LS initially practiced in Japan schools as an approach in the process of teacher's professional development that can improve students' learning experience and quality that teachers facilitated Cerbin and Kopp (2006); Lewis and Perry (2006) which is proven enable to improve the ability of teachers to manage classes and learning (Rock \& Wilson, 2005). LS is carried out to encourage changes toward better learning practices and outcome as well as fostering teacher competency and collegiality that have been applied in many areas in Indonesia and other countries. Therefore, we conducted a study of the implementation of inquiry as well as simple cooperative learning models coupled with LS-based learning practice with the aim to improve student critical and creative thinking skills as well as activeness that was the crucial issue at biology learning in MAN 1 of Bengkulu. In this study, the influence of each LS, inquiry and cooperative learning models implementation on the issue of the student's activeness, critical and creative thinking skills that existed in biology learning at this school was elaborated. 


\section{METHOD}

This study was descriptive-quantitative research. The sample was two classes that chosen randomly from seven classes of tenth-grade students of MAN 1 of Bengkulu. The LS-based inquiry learning model was conducted in one of two classes. Meanwhile, LS-based conventional-learning (simple cooperative) was conducted to another class. The learning topic in this study was the plant world or Plantae that was carried out in four cycles of LS in the even semester of 2016/2017 academic year in MAN 1 of Bengkulu. Each cycle of LS consisted of three steps, plan-do-see activities, involved collaboration among six teachers who acted as a model teacher and five observers.

An essay test and observation sheet were instruments to gather the research data. The test regarding both critical and creative thinking was conducted as the research started and ended, while the observation sheet was used to asses student activeness throughout the learning process of this research take place. The student critical thinking skills were assessed based on six indicators such as to formulate the problem, to give an argument, to do induction, to evaluate, and to take decisions and actions (Ennis, 2011). The student creative thinking skill was assessed with the criteria of fluency, flexibility, originality, elaboration, and evaluation (Scibinetti, Tocci, \& Pesce, 2011). On the other hand, the observation sheet consisted of the visual, verbal, listening, drawing, motoric, mental and emotional components of student activity in the learning process.

The research procedure comprised of three phases, i.e., preparation, implementation, and data analysis. At the first phase, the learning instruments such as syllabus, learning plan, teaching materials, student worksheets, evaluation questionnaire, chapter design, and lesson design were prepared. The second phase started with delivering pre-test of critical and creative thinking, continued with the learning process. During the learning process, the observers adhered to students' activities using the observation sheet. After that, teachers gathered to reflect and discuss the findings in the learning process and designed the better next learning. This stage ended by delivering post-test of critical and creative thinking after the fourth cycle of LS was completed. The final stage of research was to analyze the data of dependent variables by using the IBM SPSS 20 software. Prerequisite test of data normality used one sample Kolmogorov-Smirnov test, and data homogeneity used Levine test. Then, for comparing critical thinking skill as well as and creative thinking skill between inquiry and cooperative classes accomplished by using independent t-test. The student activeness between the two classes analyzed descriptively.

\section{RESULTS AND DISCUSSION}

The data of students' critical thinking skills between cooperative and inquiry classes obtained during pre-test were normal and homogeneous. Based on the t-test shows the p-value 0.41 was higher than 0.05 , it means there was no significant difference in the ability of students' critical thinking at the pre-test between cooperative and inquiry classes. Therefore, further statistical analysis to compare critical thinking skills between the inquiry and the cooperative class directly using the post-test scores, instead of using the difference between the posttest and pre-test scores. The following was the ability of student critical thinking in the cooperative and inquiry classes for both pre-test and post-test scores (Table 1).

Table 1. The critical thinking skill of students of MAN 1 of Bengkulu

\begin{tabular}{|c|c|c|c|c|}
\hline \multirow{2}{*}{ Sources } & \multicolumn{2}{|c|}{ Pre-test } & \multicolumn{2}{|c|}{ Post-test } \\
\hline & LS-Inquiry & LS-Coop. & LS-Inquiry & LS-Coop. \\
\hline Number of students & 33 & 32 & 33 & 32 \\
\hline Highest score & 50 & 40 & 100 & 80 \\
\hline Lowest score & 0 & 0 & 40 & 20 \\
\hline Total scores & 450 & 520 & 2520 & 1600 \\
\hline Mean & 13.64 & 16.25 & 76.36 & 50.00 \\
\hline Std. deviation & 6.71 & 6.18 & 8.82 & 12.44 \\
\hline Std. error & 1.16 & 1.09 & 1.53 & 2.19 \\
\hline Pre-test and post-test gain & - & - & 62.72 & 33.75 \\
\hline$p$-value of independent t-test & \multirow{2}{*}{\multicolumn{2}{|c|}{0.41}} & \multirow{2}{*}{\multicolumn{2}{|c|}{0.00}} \\
\hline Confidence degree & & & & \\
\hline
\end{tabular}

Based on normality and homogeneity test, students' critical thinking skill at post-test shows that data were normally distributed and homogeneous. The result of the t-test showed the p-value was. 0.00 was smaller than 0.05 , which means there was a significant difference in students' critical thinking skill between LS-based inquiry and cooperative-learning classes. The students in the LS-based inquiry class possesses critical thinking skill better than the LS-based cooperative class. LS-based inquiry learning improves the score of student critical 
thinking skill by 62.72 (from 13.64 to 76.36 ), almost twice the score improvement in LS-based cooperative learning by 33.75 (from 16.25 to 50.00 ).

Student creative thinking skill between cooperative and inquiry classes obtained during pre-test and posttest are presented in Table 2 . Student creative thinking skill was normally distributed and homogeneous. Based on the t-test indicated that the $p$-value was 0.97 , higher than 0.05 , meaning there was no significant difference in the ability of students critically thinking of the pre-test between cooperative and inquiry classes.

Table 2. The creative thinking skill of students of MAN 1 of Bengkulu

\begin{tabular}{|c|c|c|c|c|}
\hline \multirow{2}{*}{ Sources } & \multicolumn{2}{|c|}{ Pre-test } & \multicolumn{2}{|c|}{ Post-test } \\
\hline & LS-Inquiry & LS-Coop. & LS-Inquiry & LS-Coop. \\
\hline Number of students & 33 & 32 & 33 & 32 \\
\hline Highest Score & 60 & 60 & 100 & 40 \\
\hline Lowest score & 0 & 10 & 50 & 20 \\
\hline Total scores & 1140 & 1110 & 2460 & 1780 \\
\hline Mean & 35.63 & 34.69 & 74.55 & 55.63 \\
\hline Std. deviation & 8.66 & 7.72 & 7,29 & 8,70 \\
\hline Std. error & 1.50 & 1.36 & 1,27 & 1,53 \\
\hline Pre-test and post-test gain & - & - & 38.92 & 20.94 \\
\hline$p$-value of independent t-test & \multirow{2}{*}{\multicolumn{2}{|c|}{0.95}} & \multirow{2}{*}{\multicolumn{2}{|c|}{0.00}} \\
\hline Confidence degree & & & & \\
\hline
\end{tabular}

Table 2 shows that the results of the test of students' creative thinking skill after the research were completed at the inquiry class higher than the cooperative class. Based on the t-test, the p-value 0.00 , was smaller than 0.05 . Thus, there was a significant difference in students' creative thinking skill between LS-based inquiry and cooperative classes. Students in the inquiry class with the LS-based inquiry model had better creative thinking skill compared to the cooperative class. LS-based inquiry learning improves the score of student creative thinking skill by 38.92 (from 35.63 to 74.55 ), almost twice of the score improvement in LSbased cooperative learning by 20.94 (from 34.69 to 55.63 ).

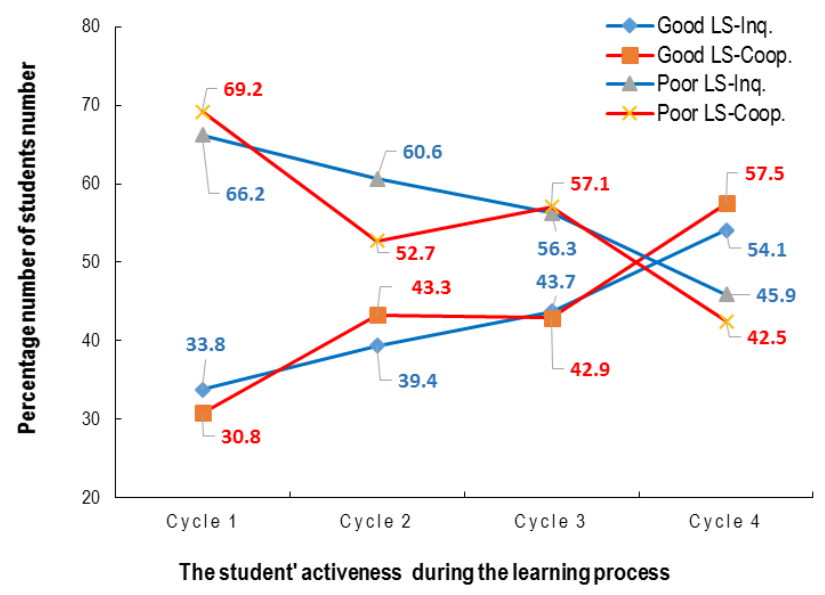

Figure 1. The number of students who showed the level of activeness in each cycles of LS-based inquiry and cooperative learnings.

The student activeness that was separated into two categories called good and poor, during learning processes of LS-based inquiry and simple cooperative were recorded in every LS cycle as shown in Figure 1. There was improvement gradually in both inquiry and cooperative classes from cycle to cycle with the highest number for the students who performed most active reach at the fourth cycle. Nevertheless, the number of students represented by the percentage value as shown in Figure 1 shows that the activity of students between the two classes was relatively similar to the same category in every cycle of LS. Data analysis using t-test shows no difference significantly among pairs in the same categories of student activeness between inquiry and cooperative classes. Therefore, the improvement of the student activeness in the LS-based learning practices as can be seen from the first until the fourth cycle of LS was not influenced by the difference of learning model between inquiry and simple cooperative learning models.

Table 3 shows the detail component of the student activeness at the final cycle of LS in this research on Plantae topic. It reinforces the data in Figure 1 that the student activeness between the inquiry and cooperative classes was comparable cumulatively. The students' activeness distributes evenly in every component 
recorded in the same category for each class. The number of students who showed good activeness in the inquiry class range from 16 to 22 while in the cooperative class range from 15 to 22 . Whereas, the quantities of the students who categorized poor, range from 11 to 17 and 10 to 17 for inquiry and cooperative classes, respectively. However, there was slightly difference descriptively in some pairs of the component of learning activities between the inquiry and cooperative classes, such as visual, oral and drawing activities in the good category between the two classes.

Table 3. Student activeness in inquiry and cooperative learning of cycle fourth LS

\begin{tabular}{cccccc}
\hline \multirow{2}{*}{ No } & \multirow{2}{*}{ Learning activities } & \multicolumn{2}{c}{ LS-Inquiry } & \multicolumn{2}{c}{ LS-Cooperative } \\
\cline { 3 - 5 } & Good & Poor & Good & Poor \\
\hline 1 & Visual activity & 22.0 & 11.0 & 17.0 & 15.0 \\
2 & Oral activity & 16.0 & 17.0 & 22.0 & 10.0 \\
3 & Listening activity & 17.0 & 15.0 & 17.0 & 15.0 \\
4 & Drawing activity & 16.0 & 17.0 & 20.0 & 12.0 \\
5 & Motor activity & 19.0 & 14.0 & 21.0 & 11.0 \\
6 & Mental activity & 17.0 & 15.0 & 15.0 & 17.0 \\
7 & Emotional activity & 18.0 & 15.0 & 17.0 & 15.0 \\
8 & Visual activity & 54.1 & 45.9 & 57.6 & 42.4 \\
9 & Oral activity & 22.0 & 11.0 & 17.0 & 15.0 \\
\hline & Percentage of students' number & 54.1 & 45.9 & 57.6 & 42.4 \\
\hline
\end{tabular}

Overall, the results of this study indicate that the application of learning plans with LS-based inquiry model was able to improve the critical and creative thinking skills of students. This increase was not only indicated by the improvement of post-test from pre-test scores of dependent variables between inquiry and cooperative classes (Table 1 and Table 2) that support the result of the study reported by Miri, David, and Uri (2007), but also the post-test score of inquiry class was significantly higher than those of the cooperative (Gengarelly \& Abrams, 2009). During the LS application carried out in combining with either inquiry or cooperative model, teachers performed the good willingness to collaborate and prepare the lesson plan, observe and review lesson implementation, which eventually had an impact on improving the quality of learning. The team of teachers (including teacher model and observer teachers) drew up a learning plan focused on the inquiry strategy with the arguments that the method was suitable for learning in biology especially in Plantae material. LS-based learning practice application was one of the ways in improving teacher professionalism due to the group of teachers consciously perceives and benefits from its application Smith (2013) especially for the younger teacher with less experience (Cajkler, Wood, Norton, \& Pedder, 2013; Guleker, 2015; Wood, 2018).

The implementation of the inquiry learning strategy showed a significant impact on student learning activeness that leads to the improvement of the ability to think critically and creatively (Retno \& Yuhanna, 2016; Rospitasari, Harahap, \& Derlina, 2017). In this case, the ability was a form of thinking ability that involves brain activity and high-level cognitive process Canzoneri, di Pellegrino, Herbelin, Blanke, and Serino (2016); Shivhare and Kumar (2016) as a very important skill in the 21 st-Century for the student to possess. The process of thinking and acquiring of comprehension of biological learning material in the cognitive structure of students is not an easy thing to do (Bensley \& Spero, 2014). It requires certain techniques and ways that are arranged in the learning plan. In this case, it seems that the stimulus prepared by the teacher succeeded in improving student activeness both in the inquiry class (inquiry learning) and in the cooperative class (simple cooperative learning) strategies. Of the four LS cycles applied, the students' activeness increased gradually in the two-learning model but comparing it between LS-based inquiry and LS-based cooperative models statistically, showed no significant difference. The increase of student's activeness in LSbased practice coupled with the inquiry learning directly improve their critical and creative thinking skills (Susetyarini \& Miharja, 2017). Otherwise, the increase of student's activeness in LS-based practice coupled with cooperative learning did not improve their critical and creative thinking. This condition becomes an interesting discussion to be conveyed which. The group of teachers in a professional manner had been able to develop good learning plan so that the difference variable that dominated the influence toward the critical and creative thinking skills and the activeness of students can be identified (Chong \& Kong, 2012; Maryani, Martaningsih, \& Bhakti, 2017). This result indicated that LS-based activity capable of improving student activeness, as it did not happen at the cooperative learning without LS that backgrounded to do this research.

LS-based inquiry learning increases students' critical thinking skill score by 62.72 , almost double compared to the score for the same indicators in learning with LS-based simple cooperative (33.75). In the learning processes were carried out, the students likely able to demonstrate ability in formulate problems, to 
give arguments, to do induction, to evaluate, and to take decisions and actions. Similarly, for the indicators of creative thinking skill. It showed that LS-based inquiry learning could increase students' critical and creative thinking abilities. In contrast, LS-based cooperative learning could not improve those skills. In this study, it shows the inquiry learning has the potential to develop students' abilities that directed toward the improvement of their critical and creative thinking skills. The result of this study strengthens the previous finding of the inquiry learning that implemented with different strategy increased the critical and creative thinking skills. The critical thinking was increased by accommodating of knowledge and motivation (Prayogi, Yuanita, \& Wasis, 2017), community-based approach (Quitadamo, Faiola, Johnson, \& Kurtz, 2008). The implementation of inquiry provides many opportunities for students to develop and improve their better creative thinking by accommodating the aspects of knowledge, motivation, and thinking skill (Prayogi et al., 2017), providing scientific attitude (Sandika \& Fitrihidajati, 2018), and mastering science process skill (Rospitasari et al., 2017; Thompson, 2017). The syntax of the inquiry model was suitable for developing students' creative thinking skills. The steps of creative thinking which include the preparation stage was developed in the syntax of inquiry models called formulating problems while the steps of students' creative thinking in the verification phase develop the syntax of the testing hypothesis.

The critical thinking is difficult to do and to teach due to it is not a set-out ability that can be utilized or spread whenever toward whatever context proses of thinking is closely associated to the student being thought about (Willingham, 2008). In our study, the application of inquiry makes students stronger in understanding the flow of scientific thinking in inquiry syntax to encourage them to think more systematically in facing a problem. The LS that coupling inquiry in this study guided and make teachers engage and implement either inquiry strategy or cooperative learning in a proper way and successfully bring about the change in their practices that conform to their students need so that increased the learning quality as well as the student activeness at a time.

\section{CONCLUSION}

LS-based inquiry learning can improve the ability of students' critically and creative thinking skills as well as student' activeness in the learning process. Combining these strategies seem that the LS directs inquiry steps appropriately so that the teacher can reflect and revise learning strategy just after every LS cycle implemented for the improvement of the learning according to the needs of the students. Therefore, increasing student activeness in LS-based inquiry learning leads the students to implement scientific steps in this learning model which in turn improves students' critical and creative thinking skills in this case mainly on the Plantae material. On the other hand, LS-based cooperative learning can only improve students' activeness but cannot improve the critical and creative thinking skills. Further study regarding of LS-based leaning that combines with other innovative models needed to be carried out in improving learning quality.

\section{REFERENCES}

Bellanca, J., Brandt, R., Barell, J., Darling-Hammond, L., Dede, C., Dufour, R., ... Seif, E. (2010). 21st century skills: Rethinking how students learn. In J. Bellanca \& R. Brandt (Eds.), 21st century skills: Rethinking how students learn (pp. 1-27). Solution Tree Press. Retrieved from http://www.edugains.ca/resources 21CL/Research/Readings/21stCenturySkills_Re-ThinkingHowStudentsLearn.pdf

Bensley, D. A., \& Spero, R. A. (2014). Improving critical thinking skills and metacognitive monitoring through direct infusion. Thinking Skills and Creativity, 12, 55-68. doi: https://doi.org/10.1016/j.tsc.2014.02.001

Cajkler, W., Wood, P., Norton, J., \& Pedder, D. (2013). Lesson Study: towards a collaborative approach to learning in initial teacher education? Cambridge Journal of Education, 43(4), 537-554. doi: https://doi. org/10.1080/0305764X.2013.834037

Canzoneri, E., di Pellegrino, G., Herbelin, B., Blanke, O., \& Serino, A. (2016). Conceptual processing is referenced to the experienced location of the self, not to the location of the physical body. Cognition, 154, 182-192. doi: https://doi.org/10.1016/j.cognition.2016.05.016

Cerbin, W., \& Kopp, B. (2006). Lesson study as a model for building pedagogical knowledge and improving teaching. International Journal of Teaching and Learning in Higher Education, 18(3), 250-257. Retrieved from http://www.isetl.org/ijthe/pdf/JTLHE110.pdf

Chang, Y., Li, B., Chen, H., \& Chiu, F. (2014). Investigating the synergy of critical thinking and creative thinking in the course of integrated activity in Taiwan. Educational Psychology, 35(3), 341-360. doi: https://doi.org/10.1080/01443410.2014.920079 
Chong, W. H., \& Kong, C. A. (2012). Teacher collaborative learning and teacher self-efficacy: The case of lesson study. Journal of Experimental Education, 80(3), 263-283. doi: https://doi.org/10.1080/0022097 3.2011 .596854

Cremin, T., Glauert, E., Craft, A., Compton, A., \& Styliandou, F. (2015). Creative little scientists: Exploring pedagogical synergies between inquiry-based and creative approaches in Early Years science. Education 3-13: International Journal of Primary, Elementary and Early Years Education, 43(4), 404419. doi: https://doi.org/10.1080/03004279.2015.1020655

Dwyer, C. P., Hogan, M. J., \& Stewart, I. (2014). An integrated critical thinking framework for the 21st century. Thinking Skills and Creativity, 12, 43-52. doi: https://doi.org/10.1016/j.tsc.2013.12.004

Ennis, R. H. (1985). A logical basis for measuring critical thinking skills. Educational Leadership, 43(2), 44-48. Retrieved from https://pdfs.semanticscholar.org/80a7/c7d4a98987590751df4b1bd9adf747fd7aaa.pdf

Ennis, R. H. (2011). The nature of critical thinking: An outline of critical thinking dispositions and abilities. In International Conference on Thinking (pp. 1-8). Massachusetts: Massachusetts Institute of Technology. Retrieved from https://education.illinois.edu/docs/default-source/faculty-documents/robert-ennis/thenatu reofcriticalthinking_51711_000.pdf?sfvrsn=7bb51288_2

Falahudin, I., Wigati, I., \& Pujiastuti, A. (2016). Pengaruh model pembelajaran inkuiri terbimbing terhadap kemampuan berpikir kritis siswa pada pembelajaran materi pengelolaan lingkungan di SMP Negeri 2 Tanjung Lago, Kabupaten Banyuasin. Bioilmi, 2(2), 92-101. Retrieved from http://jurnal.radenfatah. ac.id/index.php/bioilmi/article/view/1133/951

Gengarelly, L. M., \& Abrams, E. D. (2009). Closing the gap: Inquiry in research and the secondary science classroom. Journal of Science Education and Technology, 18(1), 74-84. doi: https://doi.org/10.1007/ s10956-008-9134-2

Guleker, R. (2015). Instructional strategies to foster critical thinking: Self-reported practices of the faculty in Albania. International Journal of Teaching and Education, 3(4), 6-14. doi: https://doi.org/10.20472/TE. 2015.3.4.002

Huff, P. L. (2014). The goal project: A group assignment to encourage creative thinking, leadership abilities and communication skills. Accounting Education: An International Journal, 23(6), 582-594. doi: https:/l doi.org/10.1080/09639284.2014.974198

Jiang, F., \& McComas, W. F. (2015). The effects of inquiry teaching on student science achievement and attitudes: evidence from propensity score analysis of PISA data. International Journal of Science Education, 37(3), 554-576. doi: https://doi.org/10.1080/09500693.2014.1000426

Jocz, J. A., Zhai, J., \& Tan, A. L. (2014). Inquiry learning in the Singaporean context: Factors affecting student interest in school science. International Journal of Science Education, 36(15), 2596-2618. doi: https:/l doi.org/10.1080/09500693.2014.908327

Johnson, E. B. (2002). Contextual teaching and learning: What it is and why it's here to stay. California: Corwin Press. Retrieved from https://goo.gl/U3Ldxu

Kampylis, P., \& Berki, E. (2014). Nurturing creative thinking. Geneva: Unesco. Retrieved from http://www.ibe. unesco.org/sites/default/files/resources/edu-practices_25_eng.pdf

Kruit, P. M., Oostdam, R. J., Berg, E. Van Den, \& Schuitema, J. A. (2018). Assessing students' ability in performing scientific inquiry: Instruments for measuring science skills in primary education. Research in Science \& Technological Education, 36(4), 413-439. doi: https://doi.org/10.1080/02635143.2017.1421 530

Kurniawan, R. Y. (2016). Identifikasi permasalahan pendidikan di Indonesia untuk meningkatkan mutu dan profesionalisme guru. In Konvensi Nasional Pendidikan Indonesia (pp. 1415-1420). Jakarta: Universitas Negeri Jakarta. Retrieved from https://www.researchgate.net/publication/317184069_identifikasi_per masalahan_pendidikan_di_indonesia_untuk_meningkatkan_mutu_dan_profesionalisme_guru

Lai, E. R. (2011). Critical thinking: A literature review. Retrieved from https://images.pearsonassessments. com/images/tmrs/CriticalThinkingReviewFINAL.pdf

Leow, F.-T., \& Neo, M. (2014). Interactive multimedia learning: innovating classroom education in a Malaysian University. TOJET: The Turkish Online Journal of Educational Technology, 13(2), 99-110. Retrieved from http://www.tojet.net/articles/v13i2/13211.pdf

Lewis, C., \& Perry, R. (2006). Professional development through lesson study: progress and challenges in the U.S. Tsukuba Journal of Educational Study in Mathematics, 25, 89-106. Retrieved from http://www. human.tsukuba.ac.jp/ mathedu/2510.pdf

Liu, Z. K., He, J., \& Li, B. (2015). Critical and creative thinking as learning processes at top-ranking Chinese 
middle schools: possibilities and required improvements. High Ability Studies, 26(1), 139-152. doi: https://doi.org/10.1080/13598139.2015.1015501

Madhuri, G. V., Kantamreddi, V. S. S. N., \& Prakash-Goteti, L. N. S. (2012). Promoting higher order thinking skills using inquiry-based learning. European Journal of Engineering Education, 37(2), 117-123. doi: https://doi.org/10.1080/03043797.2012.661701

Maryani, I., Martaningsih, S. T., \& Bhakti, C. P. (2017). Module based on pedagogical content knowledge to increase the engagement and skills of the future teachers in designing a lesson plan. Journal of Education and Learning (EduLearn), 11(1), 91-102. doi: https://doi.org/10.11591/edulearn.v11i1.5758

Miri, B., David, B. C. C., \& Uri, Z. (2007). Purposely teaching for the promotion of higher-order thinking skills: a case of critical thinking. Research in Science Education, 37(4), 353-369. doi: https://doi.org/10.1007/ s11165-006-9029-2

Piergiovanni, P. R. (2014). Creating a critical thinker. College Teaching, 62(3), 86-93. doi: https://doi.org/ 10.1080/87567555.2014.896775

Prayogi, S., Yuanita, L., \& Wasis, W. (2017). Critical-inquiry-based-learning: Model of learning to promote critical thinking ability of pre-service teachers. IOP Conference Series: Journal of Physics, 947(1). doi: https://doi.org/10.1088/1742-6596/947/1/012013

Quitadamo, I. J., Faiola, C. L., Johnson, J. E., \& Kurtz, M. J. (2008). Community-based inquiry improves critical thinking in general education biology. CBE-Life Sciences Education, 7(3), 327-337. doi: https:// doi.org/10.1187/cbe.07-11-0097

Rahabav, P. (2016). The effectiveness of academic supervision for teachers. Journal of Education and Practice, 7(9), 47-55. Retrieved from https://files.eric.ed.gov/fulltext/EJ1095817.pdf

Retno, R. S., \& Yuhanna, W. L. (2016). The learning of science basic concept by using scientifiq inquiry to improve student's thinking, working, and scientific attitude abilities. JPBI (Jurnal Pendidikan Biologi Indonesia), 2(1), 2442-3750. doi: https://doi.org/10.22219/jpbi.v2i1.2703

Rock, T. C., \& Wilson, C. (2005). Improving teaching through lesson study. Teacher Education Quarterly, 32(1), 77-92. Retrieved from https://files.eric.ed.gov/fulltext/EJ795305.pdf

Rospitasari, R., Harahap, M. B., \& Derlina, D. (2017). The effect of scientific inquiry learning model and creative thinking skills on student's science process skills. IOSR Journal of Research \& Method in Education, 7(4), 55-57. doi: https://doi.org/10.9790/7388-0704035557

Sandika, B., \& Fitrihidajati, H. (2018). Improving creative thinking skills and scientific attitude through inquirybased learning in basic biology lecture toward students of biology education. JPBI (Jurnal Pendidikan Biologi Indonesia), 4(1), 23-28. doi: https://doi.org/10.22219/.jpbi.v4i1.5326

Schleicher, A. (2018). Pisa 2015 result in focus. doi: https://doi.org/10.1787/9789264266490-en

Schleicher, A., \& Echazarra, A. (2016). Country note - Program for international student assessment (PISA) result from PISA 2015. Retrieved from https://www.oecd.org/pisa/PISA-2015-Indonesia.pdf

Scibinetti, P., Tocci, N., \& Pesce, C. (2011). Motor creativity and creative thinking in children: The diverging role of inhibition. Creativity Research Journal, 23(3), 262-272. doi: https://doi.org/10.1080/10400419. 2011.595993

Shivhare, R., \& Kumar, C. A. (2016). On the cognitive process of abstraction. In Procedia - Procedia Computer Science (Vol. 89, pp. 243-252). doi: https://doi.org/10.1016/j.procs.2016.06.051

Smith, M. H. (2013). Findings show lesson study can be an effective model for professional development of 4H volunteers. California Agriculture, 67(1), 54-61. doi: https://doi.org/10.3733/ca.v067n01p54

Susetyarini, E., \& Miharja, F. J. (2017). The implementantion of lesson study-learning community for prospective biology teachers. International Journal of Advanced Research (IJAR), 5(10), 1228-1235. doi: https://doi.org/10.21474/IJAR01/5641

Thompson, T. (2017). Teaching creativity through inquiry science. Gifted Child Today, 40(1), 29-42. DOI: https://doi.org/10.1177/1076217516675863

Tzelepi, M., \& Papanikolaou, K. (2018). Critical thinking for personalization in communities of inquiry. In 2018 IEEE 18th International Conference on Advanced Learning Technologies (ICALT) (pp. 304-306). IEEE. doi: https://doi.org/10.1109/ICALT.2018.00077

Willingham, D. T. (2008). Critical thinking: Why is it so hard to teach? American Educator, 109(4), 21-32. doi: https://doi.org/10.3200/AEPR.109.4.21-32

Wood, K. (2018). The many faces of lesson study and learning study. International Journal for Lesson and Learning Studies, 7(1), 2-7. doi: https://doi.org/10.1108/JJLLS-10-2017-0047 